\title{
The formation of character among students of primary school teacher education in a public higher education institution in Indonesia
}

\author{
Supriyadi ${ }^{*}$ \\ Ika W. Utamining Tias² \\ Amrina Izzatika ${ }^{3}$ \\ ${ }^{1-3}$ Primary School Teacher Education, Lampung University, Bandar Lampung, Indonesia
}

\begin{abstract}
The national education system so far has not been satisfactory. Looking at this situation, several solutions have been proposed, e.g., updated version of curriculum. However, this solution is not adequate because educators are also expected to be able to prepare students' attitudes and behavior so that they can face the demands of the current situation and the dynamics of change that are rapidly developing. Changes that occur are not only in knowledge and technology but also in aspects of moral values in social life. In addition to family as a center of education, a higher education institution environment also requires a function of character education to shape students' personality be more positive as expected. In other words, the process of character formation and habituation is the responsibility of not only students' parents within family domain but also formal higher education institutions. With the various problems that exist at higher education level, character building for primary teacher education (henceforth PGSD) students is needed that they are expected to be able to improve and apply their knowledge, study, appreciate and apply character values in their daily life behavior. Therefore, the purpose of this study is to identify PGSD students' character formation and ensure the results of the character formation process in a higher education institution in Indonesia.
\end{abstract}

\section{KEYWORDS}

Higher education

institution; character

building; formation; PGSD

students

Received: 2 February 2021

Accepted: 3 February 2021

Published: 4 February 2021

\section{Introduction}

Education is the most important factor in shaping a character starting from a person's values, attitudes, and behavior. Realizing the importance of the educational process in improving the quality of human resources, both government and private sectors continue to strive to realize these efforts where students are not only equipped with knowledge, but are also educated, guided, and matured, equipped with values, rules, manners, manners, customs. and culture. The national education system functions to develop abilities and shape the character and civilization of the nation with dignity to educate the nation's life, aiming at developing the potential of students to

\footnotetext{
CONTACT Supriyadi (M) supriyadi.fkip@gmail.com
} 
become human beings who believe and have devotion to God Almighty, have a noble character, are healthy, knowledgeable, competent, creative, independent and be a responsible citizen.

National education is the basis for the development of cultural education and the nation's character environment which aims to develop abilities and shape characters and build students' mindsets, attitudes and behavior. The process of character formation and habituation is the responsibility of not only parents within family domain but also formal higher education institutions. With the various problems that exist at higher education institutions, character building for students of primary teacher education (henceforth) PGSD is needed that they are expected to be able to improve and apply their knowledge, study, appreciate and apply character values in their daily life behavior in the future. Therefore, the purpose of this research is to identify students' character formation and ensure the results of the character formation process in a public higher education institution in Indonesia.

Character education teaches habits of thinking and behavior that help individuals to live and work together as a family, community, and state and help them to make responsible decisions. Character building in this country is a manifestation of the implementation of the basic mandate of Pancasila and the Preamble of the 1945 Constitution of the Republic of Indonesia. Based on this mandate, citizens should be able to respond and improve the reality of national problems that are currently developing, including ethical values in the life of the nation and the state, an awareness that is starting to fade towards the values of the nation's culture, the threat of national disintegration, and faith and piety, personality, noble character, and independence. Therefore, educational institutions, including tertiary institutions, have a strategic role in building students' character that they become a superior, noble, and generation of the nation with characters.

The World Declaration on Higher Education of the Twenty-First Century, Vision and Action by UNESCO emphasized that the vision and core value of higher education is to contribute to sustainable development and development of society as a whole. In that context, one of the visions and functions of higher education is to educate students to meet the needs of all sectors of human activity, to instill professionalism and personality through a combination of knowledge with courses that are continuously evaluated and developed, to answer the various needs of today's society and the future.

According to Istiningsih (2018), the formation of national character in schools aims to develop the ability of students to make good and bad decisions, maintain what is good, and realize that goodness in daily life wholeheartedly. Although there are a large number of character-building values, for the sake of shaping the character of the nation at this time it is based on the values that have been identified. According to the Ministry of National Education (2011), 18 character values that have been identified need to be instilled in students in terms of Religion, Pancasila, Culture, and National Education Goals. The eighteen values are: 1) religious, 2) honest, 3) tolerance, 4) discipline, 5) hard work, 6) creative, 7) independent, 8) democratic, 9) curiosity, 10) spirit of nationality, 11) love the country, 12) respect achievement, 13) friendly/communicative, 14) love peace, 15) love to read, 16) care about the environment, 17) care socially, 18) responsibility.

\section{Research Methods}

\section{Research design}

This research adopted a quantitative design with an exploratory-descriptive type of research, namely the collection of complete information and data to describe exploratively about the character building of students in a public higher education institution. Arikunto (2014) argues that descriptive research is a research method that aims to describe something, for example circumstances, conditions, situations, events and activities. Descriptive research has the characteristic of describing something based on actual conditions, without any action or behavior that can affect it. The existing conditions are described in the absence of regulated conditions or outside influences. This research is exploratory in nature. According to Arikunto (2014), exploratory research is a research that tries to explore the causes of something happening. Exploratory research also tries to dig up new knowledge to find out a problem that is or may occur. Therefore, this study 
was aimed at exploring information, describing, and finding out the character formation of students and ensure the results of character formation process. The variables of this study were 18 types of characters, namely: religious, honest, tolerant, disciplined, hard working, creative, independent, democratic, curiosity, national spirit, love of the country, respect for achievement, communicative, peace-loving, fond of reading, caring for the environment, caring socially, and being responsible.

\section{Population and research participants}

Population is the whole of the object/subject to be studied. Sugiyono (2016) states that population is a generalization area consisting of objects/subjects that have certain qualities and characteristics that are determined by researchers to be studied. The population in this study were students in semester II and VI of the PGSD Study Program of a public university in Lampung province. The number of students in semester II was 95 and semester VI were 95.

The research sample is part of the study population. The research sample is part of the number and characteristics of the population. The research sample must be truly representative, meaning that it can describe the actual situation of the population. The technique used in this research was saturated sampling, so all members of the population are sampled. This is done when the population is relatively small (Sugiyono, 2016).

\section{Instruments}

A set of instruments was employed for data collection including observation, which can be defined as a technique of collecting data through direct observation or field observation and systematic recording of the phenomena being investigated, and questionnaire through questions or written statements addressed to research respondents to respond to (Sugiyono, 2016).

The collected data were in the form of perceptions, knowledge, learning experiences, and practices about the noble values of character that are embedded in each individual student. This questionnaire was created using a Likert model which had four possible answers, which was even numbered. This was intended to avoid the tendency of respondents to be hesitant and not have clear answers. The variables to be measured were translated into a variable indicator using a Likert scale. Then the indicators were used as benchmarks for arranging instrument items which could be in the form of questions or statements.

Table 1. Questionnaire answer assessment score

\begin{tabular}{ll}
\hline Form of answer choices & Score \\
\hline Always & 4 \\
Often & 3 \\
Rarely & 2 \\
Never & 1 \\
\hline
\end{tabular}

Before the research instrument was used to obtain research data from the sample, validity and reliability testing of the instrument was done. The instrument was tested among members of the population, because this study used total sampling. Respondents who were determined in the validity and reliability tests of the instrument were 30 students. The validity test was undertaken through a Product Moment Correlation formula proposed by Pearson (as cited in Muncarno, 2015) with the following formula:

$$
\mathbf{r}_{\mathbf{x y}}=\frac{\mathbf{N} \sum \mathbf{X Y}-\left(\sum \mathbf{X}\right)\left(\sum \mathbf{Y}\right)}{\sqrt{\left\{\mathbf{N} \mathbf{\Sigma} \mathbf{X}^{2}-(\mathbf{\Sigma} \mathbf{X})^{2}\right\} \cdot\left\{\mathbf{N} \boldsymbol{\Sigma} \mathbf{Y}^{2}-(\mathbf{\Sigma} \mathbf{Y})^{2}\right\}}}
$$

Note:

$\mathrm{r}_{\mathrm{xy}} \quad=$ The coefficient between the variables $\mathrm{X}$ and $\mathrm{Y}$

$\mathrm{N} \quad=$ Number of samples

$\mathrm{X} \quad=$ Item score

$\mathrm{Y} \quad=$ Total score

Distribution $/ \mathrm{r}_{\text {table }}$ for $\alpha=0.05$ 
Decision rule: If $\mathrm{r}_{\text {count }}>\mathrm{r}_{\text {table }}$ means valid, otherwise, if $\mathrm{r}_{\text {count }}<\mathrm{r}_{\text {table }}$ means invalid or dropped out.

Valid instruments are not necessarily reliable. A reliable instrument is an instrument that, when used several times to measure the same object, will produce the same data. The calculation to find the instrument reliability was based on the opinion of Kasmadi and Nia (2014) who state that to calculate reliability, the alpha Cronbach correlation formula can be used, namely:

$$
\mathbf{r}_{11}=\left(\frac{\mathrm{n}}{\mathrm{n}-\mathbf{1}}\right) \cdot\left(1-\frac{\Sigma \sigma_{\mathbf{i}}}{\sigma_{\text {total }}}\right)
$$

Note:

$\mathrm{R}_{11} \quad=$ Instrument reliability

$\Sigma \sigma_{\mathrm{i}} \quad=$ The variance of the score for each item

$\Sigma_{\text {total }} \quad=$ Total variant

$\mathrm{n} \quad=$ Many questions

To find the variance of the score for each item $\left(\sigma_{\mathrm{i}}\right)$, the formula is used:

$$
\boldsymbol{\sigma}_{\mathbf{i}}=\frac{\sum \mathbf{X}_{\mathbf{i}}^{2}-\frac{\left(\sum \mathbf{X}_{\mathbf{i}}\right)^{2}}{\mathbf{N}}}{\mathbf{N}}
$$

Note:

$\sigma_{\mathrm{i}} \quad=$ The variance of the score for each item

$\Sigma \mathrm{X}_{\mathrm{i}} \quad=$ Number of items $\mathrm{X}_{\mathrm{i}}$

$\mathrm{N} \quad=$ Number of respondents

Next, to find the total variance $\left(\sigma_{\text {total }}\right)$ with the formula:

$$
\sigma_{\text {total }}=\frac{\sum \mathbf{X}_{\text {total }}^{2}-\frac{\left(\sum \mathbf{X}_{\text {total }}\right)^{2}}{\mathbf{N}}}{\mathbf{N}}
$$

Note:

$$
\begin{array}{ll}
\Sigma_{\text {total }} & =\text { Total variance } \\
\Sigma X_{\text {total }} & =\mathrm{X} \text { total } \\
\mathrm{N} & =\text { Number of respondents }
\end{array}
$$

The results of the calculation of the Cronbach alpha (r11) correlation formula were consulted with the product moment $r$ table value with $\mathrm{dk}=\mathrm{N}-1$, and $\alpha$ of $5 \%$ or 0.05 , then the decision rule is as follows:

If $\mathrm{r} 11>\mathrm{r}_{\text {table }}$ means reliable, whereas if $\mathrm{r} 11<\mathrm{r}_{\text {table }}$ means not reliable.

\section{Results and discussion}

After obtaining valid and reliable data instruments, the next step was to collect data by distributing questionnaires. The questionnaire, with a total of 25 questions/statements, was distributed to 190 respondents. After distributing the questionnaires and undertaking a data analysis, it can be seen that the total score is 14622 with the highest total score reaching 19000. Next was to do a percentage of the total score with a result of $76.96 \%$. Therefore, it can be stated that the percentage of the character of students under investigation was $76.96 \%$, which was at a very good level. 


\section{Conclusion}

Based on the results of data analysis and research discussion, it can be concluded that the percentage of the character of students under investigation was $76.96 \%$ falling into a very good level. In a broader context, this research is expected to be able to produce outcomes for the development of education in Indonesia, both in terms of the packaging of learning plans and the implementation of learning.

\section{Acknowledgements}

We would like to express our gratitude to all respondents taking part in the current study and to the anonymous reviewers for providing us with constructive feedback on the earlier version of our paper.

\section{References}

Arikunto, S. (2014). Prosedur penelitian: Suatu pendekatan praktik. Rineka cipta.

Istiningsih, Siti. (2018). Penumbuhan budi pekerti di sekolah melalui implementasi kurikulum 2013. Mataram: Universitas Mataram.

Kasmadi \& Nia Siti Sunariah. (2014). Panduan modern penelitian kuantitatif. Alfabeta. Bandung.

Kemendiknas. (2011). Panduan pelaksanaan pendidikan karakter. Badan Penelitian dan Pengembangan Pusat Kurikulum dan Perbukuan. Jakarta.

Muncarno. (2015). Statistik pendidikan. hamim group. Metro-Lampung.Pemerintah Republik Indonesia. 2010. Kebijakan Nasional Pembangunan Karakter Bangsa Tahun 2010-2025. Jakarta.

Sugiyono. (2016). Metode penelitian pendidikan (pendekatan kuantitatif, kualitatif, dan $R \& D$. Alfabeta. Bandung. 